\title{
Erodibility Potential of a Sand Dredging Site in Rivers State, Nigeria
}

\author{
Npinwa $\mathrm{BG}^{1}$, Nwankwoala $\mathrm{HO}^{2 *}$ and Youdeowei $\mathrm{PO}^{3}$ \\ ${ }^{1}$ Department of Civil Engineering, Rivers State University, Nigeria \\ ${ }^{2}$ Department of Geology, University of Port Harcourt, Nigeria \\ ${ }^{3}$ Institute of Geosciences and Space Technology, Rivers State University, Port Harcourt, Nigeria
}

*Corresponding author: Nwankwoala HO, Department of Geology, Faculty of Science, University of Port Harcourt, Nigeria.

Received Date: March 13, 2019

Published Date: March 19, 2019

\begin{abstract}
This study aims at determining sand erodibility potential using sand properties of the wetland, comprising different soil groups or types. Mathematical formation, tables and charts were used for the evaluation. Investigated soil properties included Sand Organic Matter (SOM), granulometry of sand, soil structure and permeability. The determined erodibility factors, hence soil erodibility potentials were significantly high. Percentage of soil organic matter was significantly low. Percentage of sand was generally high (99.33 on sieve number 4) and (95.44 on sieve number 8) using the MIT/British standard classification. However, the study provided baseline information on wetland erodibility for the reduction of soil susceptibility to erosion when considering any appropriate wetland development projects. To dredge sand and other materials for use in construction industry, principally for use in concrete, it is recommended that dredging activity may be carried out on the site.
\end{abstract}

Keywords: Erodibility; Soil susceptibility; Permeability; Wetland; Dredging; Soil properties

\section{Introduction}

Dredging operations entail the removal of bed materials and associated vegetation from a river channel. It is an underwater excavation to re-establish a channel so as to improve navigation or for commercial activities [1]. The dredged materials may be deposited in uniform layers over wet land vegetation or open bay bottom [2]. In Nigeria, manual dredging by natives has been in operation since the early part of the 19th century. This according to Aroh [3] was to get sharp sand (for construction purposes) and prevent sinking of boats. Sand erosion is a gradual change that is difficult to determine from environmental agents e.g. rainfall, runoff, streams and wind solely but coupled with dredging activity, sand erosion is determinable. Sand erosion is generally a three-step process of sand particles detachment, particles transportation or particles displacement and finally deposition at a different or new location [4]. Sand itself is a material with lesser degree of cohesion and therefore is vulnerable. The susceptibility of sand surface to the vagaries of erosion defines sand erodibility.
Sand physical properties, namely particle size distribution (soil texture), structure, organic matter content and permeability govern erodibility [5]. Texture is the mix proportion of sand, silt and clay. Erodibility is high for sandy soil. Sandy soils with small amounts of fine, medium or coarse particles $(2.00 \mathrm{~mm}$ and $0.02 \mathrm{~mm})$ are found to have high erodibility. Sand structure is the aggregation of identifiable shape and bad aggregation which enables the sand to be eroded by the detachment force of a dredger. Also, sand organic matter (SOM) being highly discouraged due to heat in sand does not bind sand particles together into sticker aggregates, thereby offering no resistance to erosion. Permeability is the measure of the rate at which water percolates through sand under a head of water and is a function of sand structure, texture and bulk density, hence a function of sand particles [4]. Because of the high percolation feature of a sandy soil, erodibility is high hence erodibility can be defined by soil partcles size distribution. Particles size distribution is very important in soil conservation, engineering and management 
of such inherent properties of the sand can influence its erodibility. This study therefore is aimed at evaluating and determining sand properties as well as erodibility potentials for dredging in the area.

\section{The Study Location}

The brackish water habitat chosen for the study is the River between Aka Village in Rumuolumeni and the Eagle Island all in Obio-Akpo Local Government Area of Rivers State (Niger Delta) in Nigeria. It is about $1 \mathrm{~km}$ to the confluence of the Bonny and Rumuolumeni Rivers. This area is under severe dredging for land reclamation by Master Energy Oil and Gas Company Limited hence removing a lot of Mangrove forest [6]. The Rumuolumeni River, a tributary of Bonny River is a brackish water habitat bothering the upper reaches of the Bonny and New Calabar Rivers which interferes with municipal development. The Bonny River has a maximum width of $2 \mathrm{~km}$ and maximum depth of 15 meters and has the largest tidal volume compared to other Niger Delta Rivers [7]. This zone is a semi hot equatorial climate with a mean annual rainfall of 2405 $\mathrm{mm}$ [8]. The transition zone of the Niger Delta according to Fubara [9] coincides with the mangrove brackish water zone with its numerous inter-tidal flats and mangrove vegetation [10] to which the study location belongs. Towns around this Bonny River and transition zone are Bakana, Buguma and Abonnema all in Rivers State of Nigeria. Port Harcourt features a tropical monsoon climate with lengthy and heavy rainy season and very short dry season in the year [8]. It is only the months of December and January that truly qualify as dry season months in Port Harcourt metropolis. The Land area covers $924,000 \mathrm{~km} 2$; ground level ranges from 7.2 to 16.9m above Mean Sea Level, MSL [11] (Figure 1).

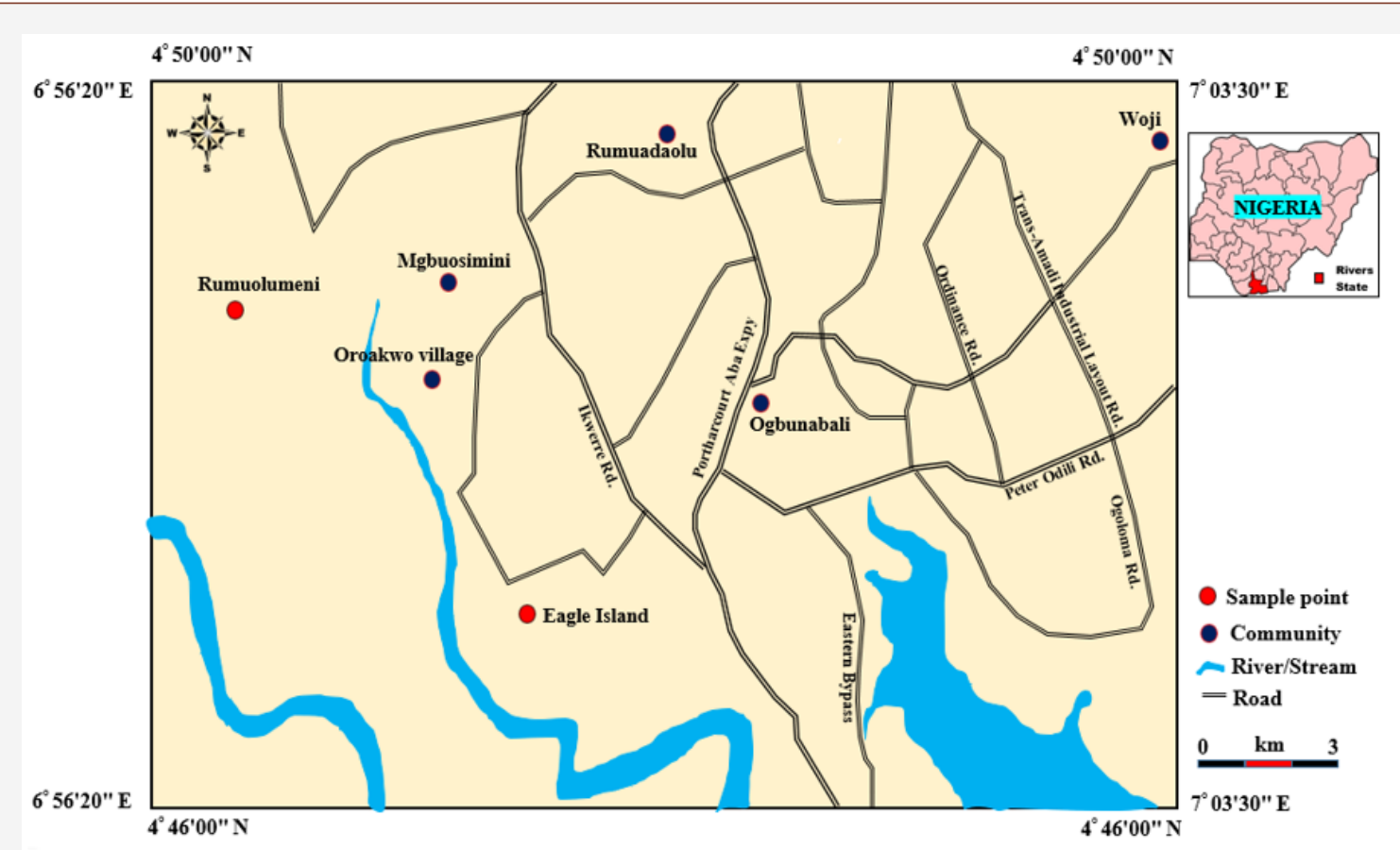

Figure 1: Map Showing the Study Area.

\section{Methods of Study}

The study involved site visits and collection of sand samples at failure zones. Samples were taken and examined by three (3) borings and for each boring, $0.5 \mathrm{~m}$ depth and $5 \mathrm{~m}$ length apart, using the hand auger from all sand horizons distinquished in the profile pits. The samples were properly labeled in plastic bags to avoid natural moisture content lost. The samples were examined, identified and roughly classified in the field and later taken to the laboratory for tests. Laboratory analyses of sand samples included: Grain size analysis, density/unit weight, specific gravity, organic matter content and direct shear strength tests. These series of tests and classification were carried out on the samples in strict compliance with relevant geotechnical engineering standards including British standards (BS 1377) and [12-17]. Simple analytical methods were used to analyze and determine sand erodibility using the sand properties.

\section{Results and Discussion}

The moisture content of the soil is the physical state of the soil with respect to moisture content present at a particular time $[18,19]$. The moisture content of the three samples of the soil was low, due to their low water holding capacity. The bulk density of the sandy soil is high compared to clayey and silty soil. The structure of the soil is sandy and could promote a network of cracks and large pores that could accommodate infiltration that result in increased erosion due to decreased runoff. From the observed high values of sand percentage, sand as a non-binder to the coarse particles accommodated high infiltration of water and it does not resist erodibility. The organic matter content of the sand is comparatively low due to heat and the particles are not bonded, hence are further precursors to erodibility. The shear resistance of a soil arises from friction and inter-locking of particles. Interlocking of the soil grains give rise to the expansion or contraction in volume of the particulate 
material that make up the entire soil mass as they are subjected to shear strains. Expansion of soil volume is accompanied by a decrease of soil density, which resulted to a decrease in strength of the soil. Sieve analysis test results for samples are shown in Figures 2, 3 and 4, respectively (Tables 1-7) (Figure 2-4).

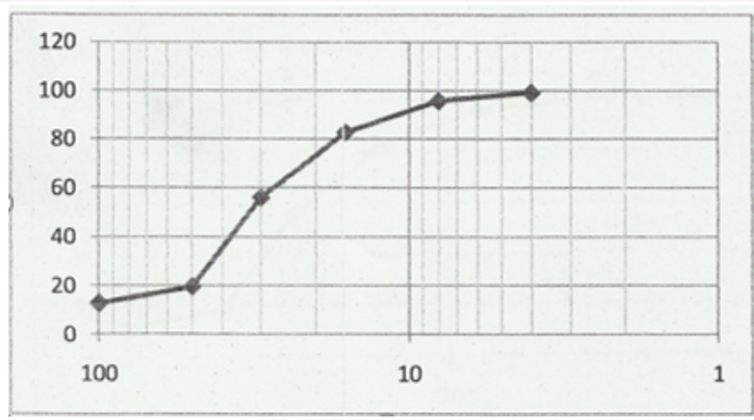

Figure 2: Sieve analysis test result for sample 1.

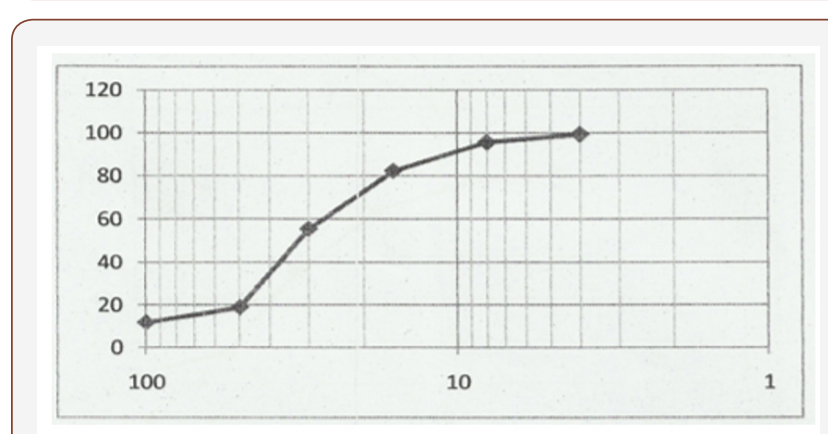

Figure 3: Sieve analysis test result for sample 2.

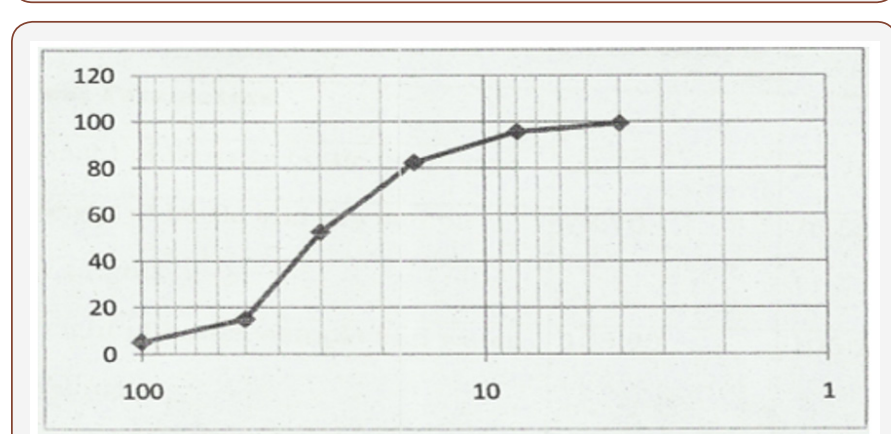

Figure 4: Sieve analysis test result for sample 3.

Table 1: Result of Moisture Content test for samples 1, 2, and 3.

\begin{tabular}{|c|c|c|c|c|c|c|}
\hline Sample No & \multicolumn{2}{|c|}{1} & \multicolumn{2}{c|}{2} & \multicolumn{2}{c|}{3} \\
\hline Container No & Aa & UC6 & Aa & UC6 & Aa & uc6 \\
\hline $\begin{array}{c}\text { Weight of Container } \\
\text { (g)- } \mathrm{W}_{1}\end{array}$ & 46 & 67.1 & 45 & 66.1 & 46 & 67.1 \\
\hline $\begin{array}{c}\text { Weight of container } \\
\text { and dry soil (g) }\end{array}$ & 45.5 & 65.7 & 44.5 & 64.7 & 45.5 & 65.7 \\
\hline $\begin{array}{c}\text { Mass of water (MW) } \\
\left(\mathrm{W}_{2}-\mathrm{W}_{3}\right)\end{array}$ & 0.5 & 1.4 & 0.5 & 1.4 & 0.5 & 1.4 \\
\hline $\begin{array}{c}\text { Mass of Dry soil (Md) } \\
\left.\text { (W- } \mathrm{W}_{3}-\mathrm{W}_{1}\right)\end{array}$ & 40.6 & 61.5 & 39.6 & 60.5 & 40.6 & 61.5 \\
\hline $\begin{array}{c}\text { Moisture content (W) } \\
\text { Mi }{ }^{7} 100\end{array}$ & $1.3: 2$ & 2.28 & 1.3 & 2.31 & 1.32 & 2.28 \\
\hline $\begin{array}{c}\text { Average moisture } \\
\text { content (W) } \%\end{array}$ & 1.8 & & 1.81 & & 1.8 & \\
\hline
\end{tabular}

Table 2: Specific gravity test result for sample 1.

\begin{tabular}{|c|c|c|}
\hline Test Parameters & & \\
\hline Weight of Density bottle $\left(\mathrm{W}_{1}\right)$ gms & 22.7 & 22.7 \\
\hline Weight of bottle and dry Sample $\left(\mathrm{W}_{2}\right)$ gms & 77.7 & 75.5 \\
\hline Weight of bottle, sample aid water & 107.9 & 106.2 \\
\hline Specific gravity Gs $=-\mathrm{j}-50-\left(\mathrm{fV}_{3} \sim \mathrm{W}_{2}\right)$ & 2.78 & 2.74 \\
\hline Average Gs & 2.76 & \\
\hline
\end{tabular}

Table 3: Specific gravity test result for sample 2.

\begin{tabular}{|c|c|c|}
\hline Test Parameters & & \\
\hline Weight of Density Bottle $\left(\mathrm{W}_{1}\right)$ gms & 22.7 & 22.7 \\
\hline Weight of Bottle and Dry Sample $\left(\mathrm{W}_{2}\right)$ gms & 78.7 & 76.5 \\
\hline Weight of bottle, sample and water $\left(\mathrm{W}_{3}\right)$ gms & 108.9 & 106.2 \\
\hline & 2.8 & 2.7 \\
\hline Average Gs & \multicolumn{2}{|c|}{2.75} \\
\hline
\end{tabular}

Table 4: Specific gravity test result for sample 3.

\begin{tabular}{|c|c|c|}
\hline Test Parameters & & \\
\hline Weight of Density bottle $\left(\mathrm{W}_{1}\right)$ gms & 22.7 & 22.7 \\
\hline Weight of bottle and dry sample $\left(\mathrm{W}_{2}\right)$ gms & 78.7 & 77.5 \\
\hline Weight of bottle, sample and water $\left\{\mathrm{W}_{3}\right)$ gms & 108.7 & 107.7 \\
\hline Specific gravity r $50-\left(\mathrm{lF}_{3}-\mathrm{Wz}\right)$ & 2.71 & 2.78 \\
\hline Average Gs & \multicolumn{2}{|c|}{2.75} \\
\hline
\end{tabular}

Table 5: Density test result for sample 1.

\begin{tabular}{|c|c|c|}
\hline Test Parameters & Test 1 & Test 2 \\
\hline Weight of Specimen and Mould (gms) & 839 & 842 \\
\hline Weight of mould only (gms) & 426 & 426 \\
\hline Weight of specimen only (gms) & 413 & 416 \\
\hline Density of specimen only $\left(\mathrm{Mg} / \mathrm{m}^{3}\right)$ & 1.78 & 1.79 \\
\hline Average Density $\left(\mathrm{Mg} / \mathrm{m}^{3}\right)$ & \multicolumn{2}{|c|}{1.79} \\
\hline Bulk Density $\left(\mathrm{kg} / \mathrm{m}^{2}\right)$ & \multicolumn{2}{|c|}{1.79} \\
\hline Unit Weight $\left(\mathrm{kN} / \mathrm{m}^{3}\right)$ & \multicolumn{2}{|c|}{17.56} \\
\hline
\end{tabular}

Volume of Mould $=2.32 \mathrm{~m}^{3}$

Table 6: Density test result for sample 2.

\begin{tabular}{|c|c|c|}
\hline Test Parameters & Test 1 & Test 2 \\
\hline Weight of Specimen and Mould (gms) & 840 & 843 \\
\hline Weight of mould only (gms) & 426 & 426 \\
\hline Weight of specimen only (gms) & 414 & 417 \\
\hline Density of specimen only $\left(\mathrm{Mg} / \mathrm{m}^{3}\right)$ & 1.78 & 1.8 \\
\hline Average Density $\left(\mathrm{Mg} / \mathrm{m}^{3}\right)$ & \multicolumn{2}{|c|}{1.79} \\
\hline Bulk Density $\left(\mathrm{kg} / \mathrm{m}^{2}\right)$ & \multicolumn{2}{|c|}{1.79} \\
\hline Unit Weight $\left(\mathrm{kN} / \mathrm{m}^{3}\right)$ & \multicolumn{2}{|c|}{17.56} \\
\hline
\end{tabular}

Volume of Mould $=2.32 \mathrm{~m}^{3}$

Table 7: Density test result for sample 3.

\begin{tabular}{|c|c|c|}
\hline Test Parameters & Test 1 & Test 2 \\
\hline Weight of Specimen and Mould (gms) & 841 & 844 \\
\hline Weight of mould only (gms) & 426 & 426 \\
\hline Weight of specimen only (gms) & 415 & 418 \\
\hline Density of specimen only $\left(\mathrm{Mg} / \mathrm{m}^{3}\right)$ & 1.79 & 1.8 \\
\hline Average Density $\left(\mathrm{Mg} / \mathrm{m}^{3}\right)$ & \multicolumn{2}{|c|}{1.8} \\
\hline
\end{tabular}




\begin{tabular}{|c|c|}
\hline Bulk Density $\left(\mathrm{kg} / \mathrm{m}^{2}\right)$ & 1800 \\
\hline Unit Weight $\left(\mathrm{kN} / \mathrm{m}^{3}\right)$ & 17.66 \\
\hline
\end{tabular}

Volume of Mould $=2.32 \mathrm{~m}^{3}$

\section{Conclusion}

The erodibility potential of a sand dredging site is comparatively high. The erodibility factor (erosion susceptibility of the site comprising many different sand series using granulometry and other inherent properties, inherent sand particles (percentage of sand), soil organic matter content as well as profile permeability class and soil structure were determined and evaluated. The identification of the erodibility classes of these inland wetlands with respect to their component soils series would benefit our knowledge of the inherent soil properties which have key roles in the prospect and ability of water erosion of their soils where the soil series are mono-dominant or mixed; also, the identified erodibility gave baseline data of the catchment wetlands thereby exposing such soils (with their vulnerable soil series) to be managed under suitable project developments that will reduce the level of soil erodibility and the prospects of wetland soil erosion. This study is also of benefit to collection of baseline data on soil erodibility of sand and providing information on erodibility to assist in reducing soil susceptibility to erosion under appropriate project development in the wetland. It is recommended that, for navigation on the waterways and to dredge sand/other materials for use in the construction industry, principally for use in concrete, dredging activity may be carried out on the site.

\section{Acknowledgement}

None.

\section{Conflict of Interest}

No conflict of interest.

\section{References}

1. Jones AR (1986) The effects of dredging and spoil disposal on Macrobenthos, Hawkesbury Estuary, N.S.W. Mar. Pollut. Bull., 17: 17-20.

2. Turner RE and B Streever (2002) Approaches to Coastal Wetland Restoration: Northern Gulf of Mexico. SPA Academic Publication, The Hague, The Netherlands.
3. Aroh E (2000) Dredging the lower river Niger: A wrong start so far Proceedings of the Environmental Impact Assessment Open Forum, Warri, Delta State, Nigeria.

4. Essien OE (2013) Evaluation of potential erodibility of basin wetland using soil particles distribution. OSR Journal of Agriculture and Veterinary Science (IOSR-JAVS) 4(4): 10-16.

5. Babalola O (1988) Soil properties affecting infiltration, runoff, and erodibility. In: Saqua VO, Enabor EE, Ofomata GEK, Ologe KO and Oyebande L (Eds.) Ecological disasters in Nigeria, Fed. Min. Sci. Tec., Lagos, Nigeria.

6. Chindah AC and SA Braide (2004) The physicochemical quality and phytoplankton community of tropical waters: A case of 4 biotopes in the lower bonny river, Niger Delta, Nigeria. Caderno de Pesquisa Serie Biol 16: 7-35.

7. NEDECO (1961) The Waters of the Niger Delta. 2nd revision Edn., The Hague Netherlands, Netherlands.

8. Gobo AE (1988) Relationship between rainfall trends and flooding in the Niger-Benue River Basin. J. Meteorol 13: 132-133.

9. Fubara DMJ, Teme SC, Mgbeke T, Gobo AET, Abam TKS (1988) Master plan Design of flood and Erosion control measures in the Niger Delta. IFERT Technical Report No. 1.

10. IGST (2000) Meteorology Division Records, Rivers State University of Science and Technology, Nkpolu-Oroworukwo, Port Harcourt.

11. Akpokodje EG (1979) The importance of engineering geological mapping in the development of the Niger Delta Basin. Bull. 1 in Assoc. Eng. Geol. No 19 pp: 102-108.

12. ASTM (1979) Annual Book of America Society for Testing and Materials Standards, 1289, Philadelphia, ASTM Tech. Publ. p. 630.

13. Peck RB, Hanson WE, Thornburn TH (1973) Foundation engineering, 2nd edn. John Wiley \& Sons, New York, USA.

14. Vickers B (1978) Laboratory Work in Soil Mechanics, Second Edition.

15. Tomlinson MJ (1999) Foundation Design and Construction $6^{\text {th }}$ Edition, Longman, p. 536.

16. Murthy VNS (1984) Soil Mechanics and Foundation Engineering, Dhanpart Rah and Sons, India.763pgs.

17. British Standard Methods of Test for soils for Civil Engineering Purposes. B.S 1377: Part 2 (1990). Published by the British Standards Institution, pp. 8-200.

18. Otunyo AW (2010) Reduction of the Shear Strength of Soils in the Niger Delta area of Nigeria due to Crude Oil Production, Nigerian Journal of Technology 29(2): 130-140.

19. Youdeowei PO and Nwankwoala HO (2013) Suitability of soils as bearing media at a freshwater swamp terrain in the Niger Delta. Journal of Geology and Mining Research 5(3): 58 -64. 